\title{
Utilization of “Uwi” Plant (Dioscorea sp.) as a Renewable Bioenergy Resource
}

\author{
Wuryantoro Wuryantoro ${ }^{1, *}$, Praptiningsih Gamawati Adinurani ${ }^{1}$, \\ Ratna Mustika Wardhani ${ }^{1}$, Sutrisno Sutrisno ${ }^{2}$,Bohari Mohammad Yamin $^{3}$ and \\ Syukri Muhammad Nur ${ }^{4,5}$
}

\begin{abstract}
${ }^{1}$ Department of Agrotechnology, Faculty of Agriculture, Merdeka University of Madiun, Jl. Serayu 79 Madiun 63133, Indonesia; ${ }^{2}$ Department of Mechanical Engineering, Faculty of Engineering, Merdeka University of Madiun, Jl. Serayu 79 Madiun 63133, Indonesia; ${ }^{3}$ Department of Chemistry, Faculty of Science and Technology, Kebangsaan University of Malaysia, 43600 UKM, 43600 Bangi, Selangor, Malaysia $;{ }^{4}$ Graduate School of Renewable Energy, Darma Persada University, Jl. Radin Inten 2, Pondok Kelapa, East Jakarta 13450, Indonesia; ${ }^{5}$ Center of Renewable Energy Studies, Darma Persada University, Jl. Radin Inten 2, Pondok Kelapa, East Jakarta 13450
\end{abstract}

Received: June, 11, 2021; Revised: Sep, 20, 2021; Accepted Oct, 16, 2021

\begin{abstract}
Many countries are currently making efforts to obtain alternative energy to reduce dependence on fossil energy resources. "Uwi" plant is a carbohydrate source that has many types and is tolerant of being planted on the upland, so it has the potential to be used as a food crop and as bioenergy. This research aims to study the potential of varieties of "uwi" (Dioscorea sp.) as raw material for ethanol production. The eight varieties of "uwi" were studied to assess their ethanol potential. The selected raw materials are Dioscorea alata L. (white yam, purple yam, and yellow yam); Dioscorea esculenta (Lour.) Burkill ("uwi gembili" and "uwi gembolo"); Dioscorea bulbifera L. ("uwi gandul"); Dioscorea pentaphylla L. ("uwi katak") and Dioscorea hispida Dennst. ("uwi gadung"). A field experiment with Randomized Block Design was used to obtain homogenous tuber raw material, followed by laboratory methods on the assessment of ethanol production potential through fermentation. The research showed that the variety, $D$. hispida had the highest ethanol content (4.94 \%), followed by D. esculenta (4.16\%) and D. alata (white yam) (3.89\%). The lowest ethanol production was obtained from $D$. pentaphylla $(0.36 \%)$ and D. bulbifera $(1.53 \%)$. However, in terms of productivity, D. alata (white-yam) is the most prospective considering its high production, ease of cultivation and tolerance of forest stands.
\end{abstract}

Keywords: Alternative energy, Bioethanol, Clean energy, Diversity, Energy plant, Root tuber crop, Upland, Yam

\section{Introduction}

Indonesia is the country with enormous energy consumption in Southeast Asia and fifth in the Asia Pacific, after China, India, Japan and South Korea. Increasing energy demand will increase along with the high average Gross Domestic Product (GDP) growth of $6.04 \%$ during 2017 to 2050. Indonesia's final energy consumption (without firewood) in 2016 was still dominated by fuel oil at $47 \%$ (Anindhita et al., 2018). The dependency on fuel is a problem because, in future time, it will run out and give emissions that harm the environment (Adinurani et al. 2017). The threat of scarcity of fossil energy has implications for an increase in the price of itself. On the other hand, Indonesia has great potential in producing renewable energy, one of which is biofuels (Adinurani et al, 2015; Tampubolon and Fauzi, 2016).

Biofuels such as bioethanol are a form of fuel that will be dominant for the future because they are renewable (Adelabu et al. 2018). The production of renewable fuels, especially from starchy materials such as root crops, has great potential to meet future energy demand. The tuber group is a promising raw material for bioethanol because it has enough carbohydrates (16\% to $24 \%)$, abundant availability and cost-effective processing (Wuryantoro et al., 2020). Root crops are a better choice for bioethanol because they are cheap and less competitive as food than grains, only about $45 \%$ of the tuber plant is consumed as food, and the rest is used for feed and industrial raw materials.

"Uwi" plant, ["uwi" is a common name in Indonesian, while in English it is called "yam" (Dioscorea sp.)] is a tuber group with lesser attention and has not received priority as a food source. This plant has many species and varieties, about 200 varieties with colours, shapes and flavours. Types of Dioscorea alata L., in particular, have colour variants and forms ranging from primary colours from white, yellow and purple, along with variations in shapes such as elongated, oblong, rounded, fingering to irregular (Wuryantoro et al., 2021). The existence of this plant is increasingly marginalized from cultivation techniques and is even allowed to grow wild. This group of tubers has excellent potential as a source of carbohydrates to use as raw material for bioethanol without disturbing food needs. "Uwi” plants are very suitable for planting in various land conditions,

\footnotetext{
* Corresponding author e-mail: wuryantoro@unmer-madiun.ac.id.
} 
especially in an upland that has not been optimally utilized. This upland area covers more than $60 \%$ of the land area in Indonesia (Hakim et al., 2017) and more than $40 \%$ in the world (UNESCO, 2020). This highlights the adaptability of "uwi" to the local climatic conditions and ability to thrive without significant climate impacts (Okongor et al., 2021). Some varieties can even be adapted to forest stands with higher production capacity (Wuryantoro et al., 2019). However, the product potential of this commodity for industrial use is still not well utilized (Andres and Adeoluwa, 2016). These plants are also crucial in socio-religious life in various countries. Research in Nigeria shows the importance of "uwi" plant in social, economic, religious and cultural fabric of society (Obidiegwu and Akbapio, 2017). In Ghana, these plants have even become an essential commodity being cultivated intensively involving men and women with various levels of education, which ultimately determines the level of productivity and farming efficiency (Tanko and Alidu, 2017). And in Cameroon, the commodity of yam is the primary buffer for food security and in overcoming poverty. There are seven species cultivated in this country, and about 17 wild species are feared for genetic erosion if there is no Gen Bank Institute to handle it immediately (Azeteh et al., 2019).

According to Hoover (2001) in Ulyarti (2016), the starch content of $D$. alata tubers reaches $80 \%$ of the total dry weight (Ulyarti and Lavlinesia, 2016). The starch content in $D$. alata tubers varies greatly depending on the cultivar and growing conditions. Sahusilawane et al. (2011) stated that this plant produces an excellent source of carbohydrates in tropical and subtropical areas. In Indonesia, Dioscorea sp. is a type of tuber plant that has not been widely cultivated and even grows as wild plants on the edge of gardens, forests or abandoned land. This plant productivity is quite high if cultivated properly; it can reach (40 to 60) $\mathrm{t} \mathrm{ha}^{-1}$. Under certain types of forest stands, they still produce (3 to 5 ) $\mathrm{kg}$ plant $^{-1}$. The results of the study by Winarti and Saputro (2013) showed the starch content of Dioscorea alata L. (yellow yam = $83.38 \%$, purple yam $=86.12 \%$, and white yam $=$ $86.68 \%$ \%), Dioscorea esculenta (Lour.) Burkill ("uwi gembili" = $82.82 \%$ ), Dioscorea pentaphylla L. ("uwi katak" = $79.27 \%$ ), and Dioscores bulbifera L. ("uwi gembolo" = $84.80 \%$ ). Due to its high starch concentration, the tuber plant is considered one of the most important first-generation feedstocks for bioethanol production. Root starch can be hydrolyzed, fermented, and then refined to produce ethanol (Thatoi et al., 2016). Starch content is a good substrate for producing glucose as an intermediate product for making bioethanol. Variations in the starch content of Dioscorea sp. may depend on several environmental factors and agronomic practices, and the degree of maturity. The difference in starch content in Dioscorea sp. requires studying to determine the potential varieties as raw material for bioethanol. The research on tuber skin yielded $12.3 \%$ bioethanol. It showed that the tubers could produce bioethanol, although not as good as cassava peels which grew $18.6 \%$, using the yeast Gloeophylum saplarium, Pleurotus ostreatus, Zymomonas mobilis and Saccharomyces cerevisiae (Adiotomre, 2015). The fermentation process has been widely used in agricultural, livestock, and fishery activities to obtain material inputs for biological productivity processes (Yasmin et al., 2020). Fermentative microbes are widely available in nature, which is accessible to isolated for various needs. It is reported that traditionally fermented vegetables are a good source of Lactobacillus probiotics (Mahasneh et al., 2020). Another study on fermentation resulted in ethanol yield of $13 \%$ and $11 \%$ from bitter yam [Dioscorea dumetorum (Kunth.) Pax.] and skin of water yam tubers (Dioscorea alata L.), respectively (Banjo et al., 2019).

\section{Materials and Method}

\subsection{Time and Place}

The research was carried out with field experiments in the Cepoko village's uplands, Ngrayun sub-district, Ponorogo district, East Java at an altitude of $700 \mathrm{~m}$ a.s.l., in the rainy season of November 2019 to June 2020. Subsequent experiments on ethanol production were carried out in the Faculty of Agriculture Laboratory, the Merdeka University of Madiun, from August 2020 to October 2020.

\subsection{Materials and Tools}

The materials used in the field experiment were eight varieties of "uwi" plants, compost and NPK "Mutiara" fertilizer $(\mathrm{N}: \mathrm{P}: \mathrm{K}=16: 16: 16)$, from $\mathrm{PT}$ Meroke, Indonesia. The equipment used is a hoe, sickle, bamboo for plant propagation, and measuring equipment such as meters, scales and calipers. For laboratory experiments, using tuber materials from field experiments, distilled water, well water, "tape" yeast brand "Kencana", Indonesian product, alpha-amylase enzyme, $\mathrm{NaOH}$. The equipment used is in the form of boiling equipment: gas stove, pan, peel knife and chopper, fermentation equipment in the form of closed jars, $\mathrm{pH}$ meters, refractometers, distillation equipment: laboratory-scale distillation, Erlenmeyer flasks, round flasks, thermometers, cooling water reservoirs, distillate containers, Bunsen heaters, gas stoves and electric stoves.

\subsection{Research method}

The field experiment used a Randomized Block Design consisting of eight treatments of "uwi" species (Dioscorea sp.), repeated three times. The treatments consisted of three sub-varities of $D$. alata (white yam, yellow yam and purple yam), two subvarietes of $D$. esculenta ("uwi gembili" and "uwi gembolo"), D. hispida ("uwi gadung"), D. bulbifera ("uwi gandul") and D. pentaphylla ("uwi katak"). Observations were made on the production of tubers after going through homogeneous cultivation techniques. The experiment used a Randomized Block Design (Ramesh et al., 2019), and as a block, the length of fermentation time was $5 \mathrm{~d}, 7 \mathrm{~d}$, and $10 \mathrm{~d}$. The eight types of "uwi" tubers from field experiments as treatments were:

$\begin{array}{ll}\text { U1 } & \text { D. alata type white yam } \\ \text { U2 } & \text { D. alata type purple yam } \\ \text { U3 } & \text { D. alata type yellow yam } \\ \text { U4 } & \text { D. esculenta type "gembili" } \\ \text { U5 } & \text { D. esculenta type "gembolo" } \\ \text { U6 } & \text { D. bulbifera ("uwi gandul") }\end{array}$


U7 D. pentaphylla (“uwi katak”)

U8 D. hispida ("uwi gadung”)

\subsection{Practices}

The study has two experimental stages. The first is a field experiment using a Randomized Block Design and soil fertility as block and repeated three times. Observations variable on the production of tubers after going through homogeneous cultivation techniques. Planting was carried out on the mounds in the treatment plot with four bunds for each treatment type and repeated in three blocks. The tuber weight for seedlings ranged from $75 \mathrm{~g}$ to $100 \mathrm{~g}$, planted at a $75 \mathrm{~cm} \times 100 \mathrm{~cm}$ spacing. When the bulbs sprout, a double-row model of propagation poles is given (Wuryantoro, 2020).

The second stage is the laboratory experiment using a randomized block design and a grouping according to fermentation time, namely $5 \mathrm{~d}, 7 \mathrm{~d}$, and $10 \mathrm{~d}$. The study used eight treatments of "uwi" tubers whose productivity had been investigated from previous field experiments. The stages of ethanol production are material preparation, stripping, cutting, boiling, administering enzymes (alpha-amylase), yeast (Saccharomyces cerevisiae) and NPK, fermentation, filtering, refining, ending with measuring ethanol production by distillation.
The measure of ethanol content taking $200 \mathrm{~mL}$ of fermented liquid samples with three repetitions, namely on the $5^{\text {th }} \mathrm{d}, 7^{\text {th }} \mathrm{d}$, and $10^{\text {th }} \mathrm{d}$ of fermentation. Observations were made on $\mathrm{pH}$ solution by $\mathrm{pH}$ meter, sugar content measure by Refractometer Brix, and ethanol content by alcohol meter. The $\mathrm{pH}$ level is measured every day to maintain $\mathrm{pH} 5$ to $\mathrm{pH} 6$ with the addition of $\mathrm{NaOH}$. Therefore, sugar and ethanol levels were observed on $5 \mathrm{~d}, 7 \mathrm{~d}$, and $10 \mathrm{~d}$, of the fermentation process. Calculation of alcohol content was made using Equation (1):

$$
E c=\frac{D E \times V f \times 100}{W s}
$$

Note: Ec; Ethanol content (\%)

DE: Density of alcohol at the rate of distillation

(Table 1)

Vf: Volume of fermentation liquid from Ws tuber material

Ws: Sample weight of tuber material

The Density value of ethanol (DE) uses the conversion table approach in Table 1 (Perry et al., 2000).

Table 1. Density conversion of ethanol at various ethanol content

\begin{tabular}{cccccccc}
\hline $\begin{array}{c}\text { Ethanol } \\
\text { content }(\%)\end{array}$ & $\begin{array}{c}\text { Density } \\
\left(30^{\circ} \mathrm{C}\right)\end{array}$ & $\begin{array}{c}\text { Ethanol } \\
\text { content }(\%)\end{array}$ & $\begin{array}{c}\text { Density } \\
\left(30{ }^{\circ} \mathrm{C}\right)\end{array}$ & $\begin{array}{c}\text { Ethanol } \\
\text { content }(\%)\end{array}$ & $\begin{array}{c}\text { Density } \\
\left(30{ }^{\circ} \mathrm{C}\right)\end{array}$ & $\begin{array}{c}\text { Ethanol } \\
\text { content }(\%)\end{array}$ & $\begin{array}{c}\text { Density } \\
\left(30^{\circ} \mathrm{C}\right)\end{array}$ \\
\hline 0 & 0.99568 & 13 & 0.97424 & 26 & 0.95442 & 39 & 0.92979 \\
1 & 0.99379 & 14 & 0.97278 & 27 & 0.95272 & 40 & 0.92770 \\
2 & 0.99194 & 15 & 0.97133 & 28 & 0.95098 & 41 & 0.92558 \\
3 & 0.99014 & 16 & 0.96990 & 29 & 0.94922 & 42 & 0.92344 \\
4 & 0.98839 & 17 & 0.96844 & 30 & 0.94741 & 43 & 0.92128 \\
5 & 0.98670 & 18 & 0.96697 & 31 & 0.94557 & 44 & 0.91910 \\
6 & 0.98507 & 19 & 0.96547 & 32 & 0.94370 & 45 & 0.91692 \\
7 & 0.98347 & 20 & 0.96395 & 33 & 0.94180 & 46 & 0.91472 \\
8 & 0.98189 & 21 & 0.96242 & 34 & 0.93986 & 47 & 0.91250 \\
9 & 0.98031 & 22 & 0.96080 & 35 & 0.93790 & 48 & 0.91028 \\
10 & 0.97875 & 23 & 0.95929 & 36 & 0.93591 & 49 & 0.90805 \\
11 & 0.97723 & 24 & 0.95769 & 37 & 0.93390 & 50 & 0.90580 \\
12 & 0.97573 & 25 & 0.95607 & 38 & 0.93186 & & \\
\hline
\end{tabular}

\section{Result and Discussion Carbohydrate and Glucose} Level

From the analysis, results of carbohydrate content of fresh tubers from eight varieties of Dioscorea sp. were observed to be between $18.80 \%$ and $26.60 \%$, sugar content before fermentation was $1.00 \%$ to $7.00 \%$ and sugar content after $10 \mathrm{~d}$ fermentation was between $0.77 \%$ and $4.10 \%$ (Figure 1).

Figure 1 also shows that the varieties with higher carbohydrate content in fresh tubers do not always produce high sugar content. The highest carbohydrate content in white yam $(D$. alata) was $26.60 \%$, with sugar content before fermentation ( $0 \mathrm{~d}$ ) was $1.2 \%$ and $10 \mathrm{~d}$ as $2.00 \%$. On the other hand, "uwi gembili " and "uwi gembolo" (D. esculenta) varieties with the lowest carbohydrate content (18.80\% and $20.62 \%$ ) produced the highest sugar content during the fermentation process, which indicates that the starch from these materials were more readily hydrolyzed into sugar. This condition causes an increase in breaking the starch polymer chains in carbohydrates of "uwi gembili" and "uwi gembolo" species into sugar.

Figure 1 also shows that the varieties with higher carbohydrate content in fresh tubers do not always produce high sugar content. The highest carbohydrate content in white yam (D. alata) was $26.60 \%$, with sugar content before fermentation $(0 \mathrm{~d})$ was $1.2 \%$ and $10 \mathrm{~d}$ as $2.00 \%$. On the other hand, "uwi gembili " and "uwi gembolo" (D. esculenta) varieties with the lowest carbohydrate content (18.80\% and $20.62 \%)$ produced the highest sugar content during the fermentation process, which indicates that the starch from these materials were more readily hydrolyzed into sugar. This condition causes an increase in breaking the starch polymer chains in carbohydrates of "uwi gembili" and "uwi gembolo" species into sugar. 


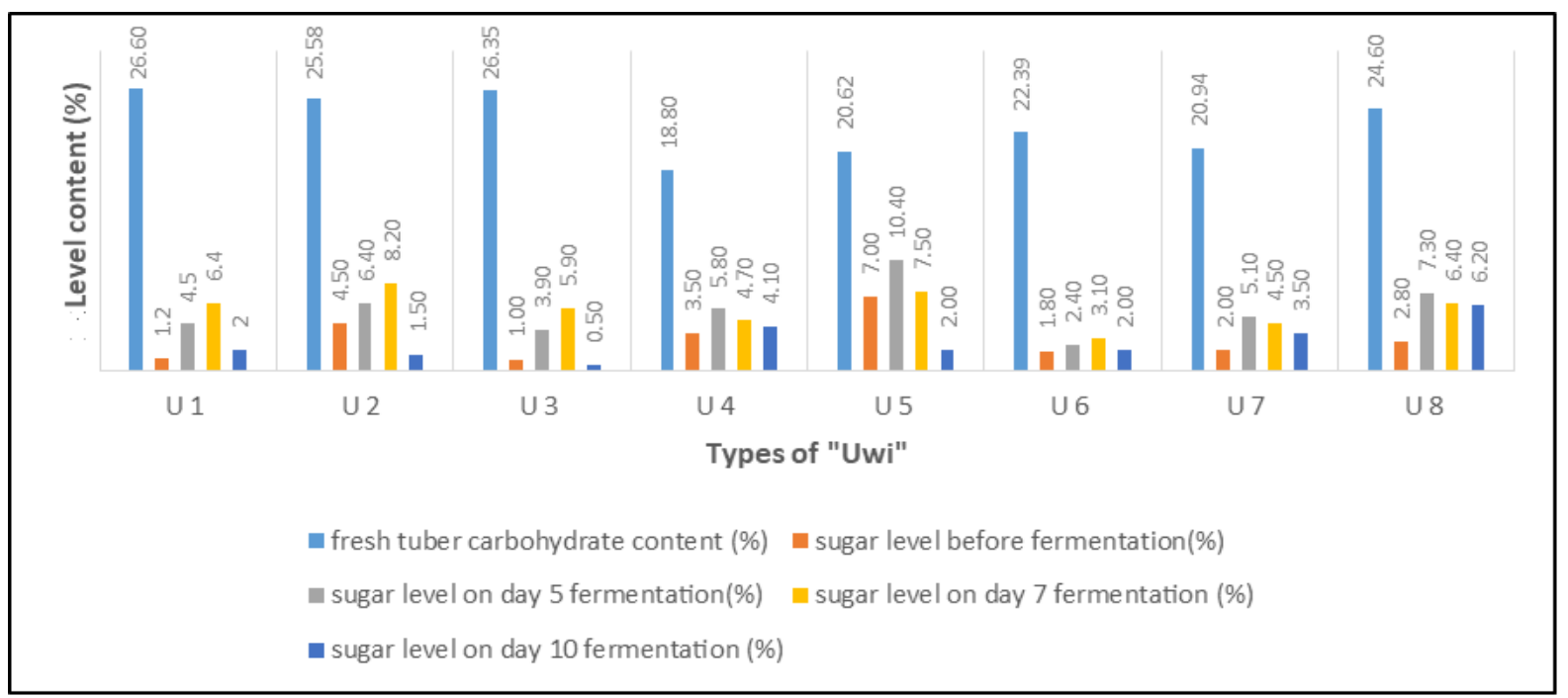

Figure 1. Carbohydrate content of fresh tubers and sugar content of various types of "uwi” at different fermentation times

The high sugar content indicates that glucose conversion to ethanol has not maximized for $10 \mathrm{~d}$ of fermentation. This speed of hydrolysis, in turn, yields higher ethanol (Table 2). At the same time, the enzymatic hydrolysis process of many carbohydrates in D. alata (white yam) needed relatively longer duration than that of "uwi gembili" to produce lower sugar levels. The $\alpha$-amylase enzyme used in hydrolysis can specifically break $\alpha-1,4$-glucoside bonds and quickly reduce the starch molecules size into a simple form, namely sugar (Praputri and Sundari, 2019). "uwi gadung” has a high starch content, and the amylase enzyme plays a role in the formation of high sugar until the $10^{\text {th }} \mathrm{d}$ of the fermentation process, which produces $4.94 \%$ ethanol although not significantly different from "uwi gembili”, "uwi gembolo", and white yam. This process is not the case if the hydrolysis runs faster and the hydrolyzed substrate contains enough sugar to be fermented as in the "uwi gembili" variety. High substrate concentrations can reduce energy use and overall water consumption. This is to increase the effectiveness of the fermentation process.

Based on Figure 1, the highest sugar content was in the "uwi gembolo" variety but did not show the maximum ethanol production. This may be due to the inhibition of reducing sugar fermentation (Raul et al. 2016). Even though the ethanol content of the "uwi gembili" variety (3.89 \%) was not high, the ethanol content produced was quite a lot and not significantly different from the ethanol content of the "uwi gembolo" (4.17\%), as shown in Table 2. These results have no significant difference from the results of the research by Yuniawati et al. (2010), carried out for the ethanol production from white yam (3.2 \%), yellow yam (2.6 \%), and purple yam (2.6 \%). For the "uwi gembolo" variety, the sugar content from the beginning was high $(7 \%)$, indicating that the starch was hydrolyzed into sugar, resulting in higher ethanol yield. The enzymatic and fermentation processes that run simultaneously require high energy and are generally in the early fermentation stages. In the beginning, the high amount of sugar converted a lot to ethanol during the fermentation process, so caused the amount to be lower at the end of fermentation. The amount of sugar available in the media is still tiny. In this condition, microbial growth is slow and affects ethanol production-the level of ethanol yield is determined by the yeast activity used with fermented sugar substrate. Microbial activity in yeast enters a death phase when there are enough sugar substrates. Therefore, the microbial population does not considerably impact ethanol production, but it significantly consumes the sugar content in the fermentation substrate (Selim et al., 2018). In the "uwi gembili" variety, the number of microbes grows slowly. Therefore, there is no increase in the number of microbes that can convert the substrate into bioethanol, thereby reducing bioethanol production. This moment causes the ethanol content produced to be not optimal.

The fermentation process can take a long time, depending on the yeast's ability to convert sugar into alcohol. In the fermentation process, microbes change the substrate that can turn into ethanol and produce enzymes to catalyze the conversion of complex carbohydrates to simpler sugars (Thatoi et al., 2016). Enzymatic and fermentation processes that run simultaneously will reduce energy input and increase the substrate (Chen-Yeon Chu et al., 2012).

Table 2. The productivity tuber of "uwi" and estimation of ethanol production

\begin{tabular}{llll}
\hline $\begin{array}{l}\text { Types of } \\
\text { “uwi” }\end{array}$ & $\begin{array}{l}\text { Tuber yield } \\
\left(\mathrm{t} \mathrm{ha}^{-1}\right)\end{array}$ & $\begin{array}{l}\text { Level of } \\
\text { ethanol }(\%)\end{array}$ & $\begin{array}{l}\text { Estimation of ethanol } \\
\text { product }\left(\mathrm{t} \mathrm{h}^{-1}\right)\end{array}$ \\
\hline $\mathrm{U} 1$ & $47.77 \mathrm{c}$ & $3.56 \mathrm{~cd}$ & $1.089 \mathrm{~cd}$ \\
$\mathrm{U} 2$ & $57.57 \mathrm{~d}$ & $3.04 \mathrm{bc}$ & $1.141 \mathrm{~d}$ \\
$\mathrm{U} 3$ & $56.70 \mathrm{~d}$ & $2.76 \mathrm{bc}$ & $1.049 \mathrm{~cd}$ \\
$\mathrm{U} 4$ & $29.80 \mathrm{ab}$ & $3.89 \mathrm{~cd}$ & $0.517 \mathrm{abc}$ \\
$\mathrm{U} 5$ & $33.47 \mathrm{~b}$ & $4.17 \mathrm{~cd}$ & $0.687 \mathrm{bcd}$ \\
$\mathrm{U} 6$ & $25.07 \mathrm{ab}$ & $1.53 \mathrm{ab}$ & $0.162 \mathrm{ab}$ \\
$\mathrm{U} 7$ & $23.57 \mathrm{a}$ & $0.36 \mathrm{a}$ & $0.042 \mathrm{a}$ \\
$\mathrm{U} 8$ & $30.27 \mathrm{ab}$ & $4.94 \mathrm{~d}$ & $0.885 \mathrm{~cd}$ \\
\hline
\end{tabular}

Notes: The number followed by same letters, in the same column, not significant at $5 \%$ DMRT

The research results on ethanol content in the varieties of Dioscorea sp. did not show linearity in the relationship of sugar content with ethanol yield. The relationship between $10^{\text {th }} \mathrm{d}$ fermentation substrate sugar content and ethanol content follows the equation $\mathrm{y}=2.815+0.025 \mathrm{x}$. 
$\mathrm{R} 2=0.001$, which indicates that the effect of sugar content on the $10^{\text {th }} \mathrm{d}$ fermentation ethanol yield is insignificant. The results also showed that the ethanol yield on $5^{\text {th }} \mathrm{d}$, $7^{\text {th }} \mathrm{d}$ and $10^{\text {th }} \mathrm{d}$ was not significant, with sugar content. The high sugar content on the $10^{\text {th }} \mathrm{d}$ fermentation indicates that the activity microbial was not maximum or the inhibition fermentation process. The addition of the enzyme glucoamylase seems necessary to increase sugar levels, given the relatively low glycemic index value of "uwi" plant tubers (Ramdath et al., 2004). Braide et al. (2018) showed that the maximum yield of ethanol obtained at $\mathrm{pH}$ (4.0 to 4.5) for Zymomonas mobilis and $\mathrm{pH}$ (4.2 to 4.5) for Saccharomyces cerevisiae. The optimum ethanol production at $72 \mathrm{~h}$ fermentation process by $Z$. mobilis was $8.36 \%(\mathrm{v} / \mathrm{v})$ and $7.39 \%(\mathrm{v} / \mathrm{v})$ by $S$. cerevisiae. The sugar concentration was reduced from (11.82 to 7.69) $\mathrm{mg} \mathrm{g}^{-1}$ and (13.08 to 7.50$) \mathrm{mg} \mathrm{g}^{-1}$ in the substrate fermented by $Z$. mobilis and S. cerevisiae. In addition, the quality of the yeast is thought to be the cause of the low ethanol content production. Another study stated that fermentation with newly isolated yeast produced more ethanol at room temperature $(11.30 \%)$ and at $80{ }^{\circ} \mathrm{C}$ (6.15\%) than fermented with baker's yeast (Olayemia et al., 2019). "Uwi" peels also had more ethanol at room temperature than at $80{ }^{\circ} \mathrm{C}$ using either of the two enzymes for fermentation (21.72\% and $27.08 \%$ ) (Olayemia et al., 2019). The research results on $D$. rotundata also revealed its potential as raw material for lactic and alcohol fermentation due to the high concentration of reducing sugars after hydrolysis. However, Saccharomyces bayanus is not suitable to replace $S$. cerevisiae in ethanol production via SSF due to its low ethanol productivity in the first $24 \mathrm{~h}$ of fermentation (Villadiego-del Villar et al., 2021)

\subsection{Ethanol Content}

The ethanol content (\%) of types of "uwi" in the three fermentation stages is shown in Figure 2.

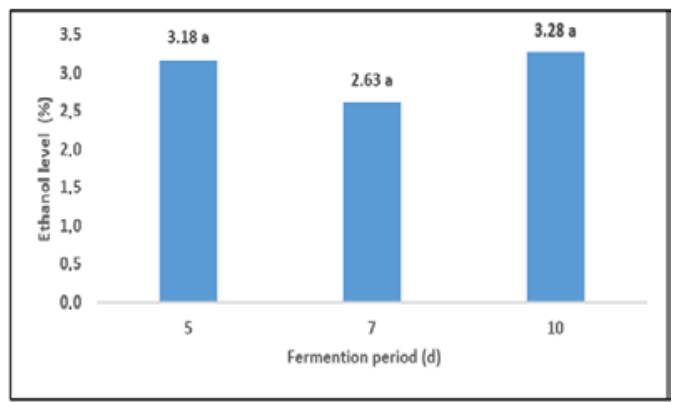

Figure 2. The average of "uwi” tuber plant ethanol content (\%) in three stages of fermentation

Figure 2 shows that the fermentation time of (5 to 10) d did not show any significant changes and differences, indicating that the fermentation process of up to $5 \mathrm{~d}$ is sufficient to convert carbohydrates into sugar and ethanol. The ethanol content did not increase until $10 \mathrm{~d}$ due to the fermentation process's delay by the high level of ethanol in the fermentation liquid, which caused the yeast to become inactive.

The amount of sugar substrate produced from the hydrolysis process seems to be an obstacle in increasing the ethanol yield. The hydrolysis process is the key to an optimum ethanol recovery from starch-based materials. The use of alpha-glucosidase enzymes and variations in hydrolysis temperature affected in increasing the rate of hydrolysis (Kusmiyati, 2010). Other studies also showed that the longer the fermentation time, the greater the bioethanol content produced until the $3^{\text {th }} \mathrm{d}$. There was a decrease in bioethanol levels the next day (Novia and Khairunnas, 2017). The research results regarding the durian (Durio zibethinus L.) seed bioethanol content revealed the optimal fermentation time of $72 \mathrm{~h}$. The fermentation of $20 \mathrm{~g} \mathrm{~L}^{-1}$ reducing sugars for $72 \mathrm{~h}$ results in the highest ethanol concentration, viz., $9.85 \mathrm{~g} \mathrm{~L}^{-1}$ (Purnomo et al., 2016). While in the other studies on Colocasia Schott plants, the resulting highest bioethanol content was $19.10 \%$ during $96 \mathrm{~h}$ fermentation using S. cerevisiae (Praputri and Sundari, 2019).

\subsection{Productivity}

The ethanol production process was determined by two factors, namely tuber-plant productivity and ethanol content of each type. The purple tuber of $D$. alata species produced the highest ethanol $\left(1.141 \mathrm{t} \mathrm{ha}^{-1}\right)$ due to increased tuber production $\left(57.57 \mathrm{t} \mathrm{ha}^{-1}\right)$, although it is not significantly different from the yellow yam. Meanwhile, "gembolo" yielded a higher ethanol yield with low tuber productivity; therefore, estimation ethanol productivity was few $\left(0.687 \mathrm{t} \mathrm{ha}^{-1}\right)$. Thus, in terms of productivity, white, purple and yellow $D$. alata variety have more potential for ethanol production (Figure 3). The tuber production process determined by many factors such as climate, soil, fertilization and other cultivation techniques such as population size, seed quality, plant varieties and others. D. alata has more variety, differentiated based mainly on the colour and shape of the tubers. The research results of $D$. alata species revealed productivity of (5 to 7) $\mathrm{kg}$ plant ${ }^{-1}$ with a spacing of $1.00 \mathrm{~cm} \times 0.75 \mathrm{~cm}$. However, the other varieties of $D$. alata had production of less than $2 \mathrm{~kg}$ per plant. The yellow yam is rarely used as food because of its unfavourable taste, which can be considered as a raw material for bioethanol. 


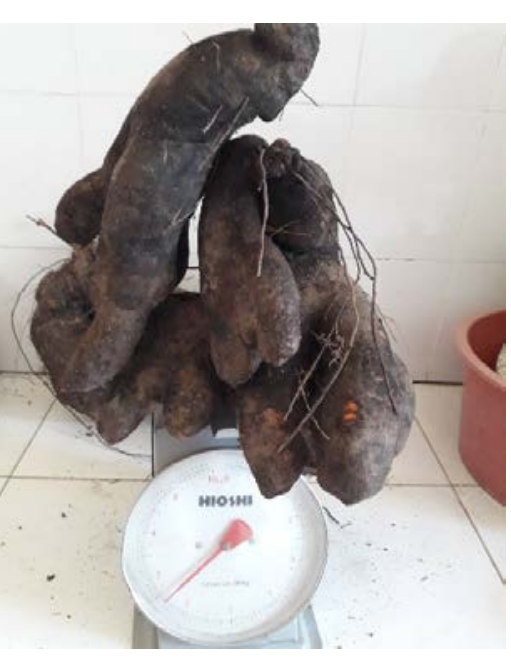

Yellow yam

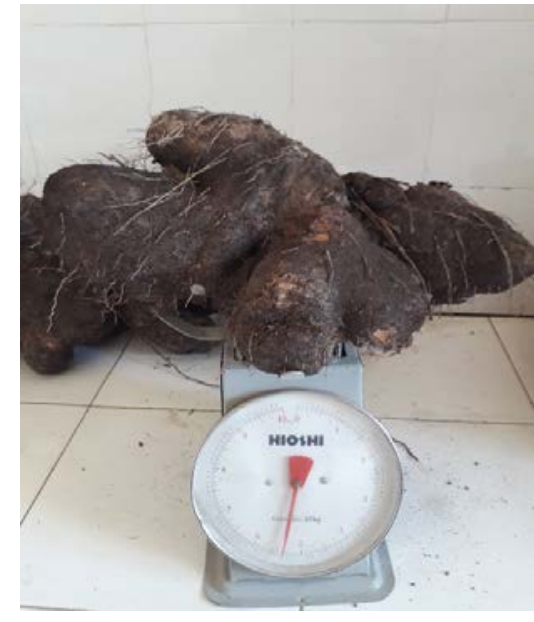

White yam

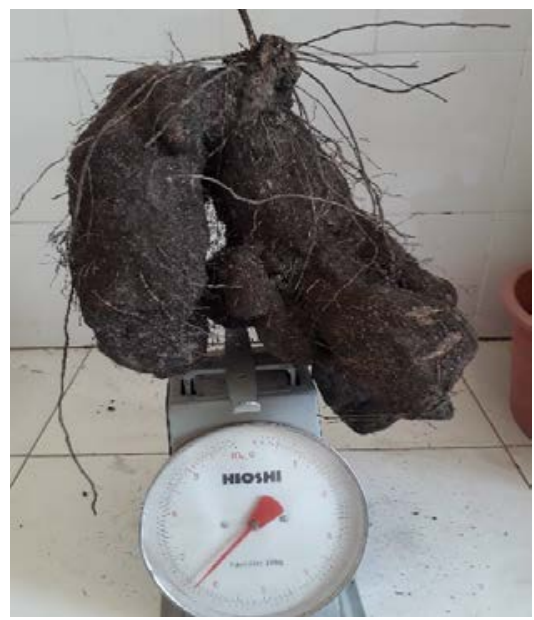

Purple yam

Figure 3. Three potential types of Dioscorea alata

\section{Conclusion}

The “uwi” plant species $D$. alata, namely white yam, purple yam and yellow yam, had the highest tuber and ethanol productivity even though the ethanol content was lower than the "uwi gadung" (D. hispida), "uwi gembolo" and "uwi gembili" (D. esculenta). High levels of tuber carbohydrates, not necessarily resulting in high ethanol yield, still depend on the speed of converting carbohydrates into sugar at the beginning and during the fermentation process. The highest percentage of ethanol yield was obtained for "uwi gadung" ( $D$. hispida) at $4.94 \%$, followed by "uwi gembolo" and "uwi gembili" at $3.89 \%$ and $4.17 \%$, and the lowest was for "uwi katak" (D. pentaphylla) at $0.36 \%$. The highest ethanol productivity was obtained by the species of "uwi kelapa" (D. alata) with production of (1.049 to 1.141) $\mathrm{t} \mathrm{ha}^{-1}$ of ethanol, considering higher tuber production.

\section{Acknowledgment}

The authors appreciate Kemenristekdikti (Ministry of Research, Technology and Higher Education of Republic of Indonesia) for funding this research, by contract number 009/KP2TJ/PTUPT/Unmer.Mdn/LPPM/III/2020, Rector of the Merdeka University of Madiun and the Dean of the Faculty of Agriculture for all facilities. Also, the entire team and students have helped get a lot of data in the field and laboratory.

\section{References}

Adelabu, BA, Kareem SO, Adeogun AI, and Ademolu KO. 2018. Direct bioconversion of sorghum straw to ethanol in a single-step process by Candida species. Jordan J. Biol. Sci. 11(1): 57-63.

Adinurani PG, Setyobudi RH, Nindita A, Wahono SK, Maizirwan M, Sasmito A, Nugroho YA, and Liwang T. 2015. Characterization of Jatropha curcas Linn. capsule husk as feedstock for anaerobic digestion. Energy Procedia 65:264-273

Adinurani PG, Setyobudi RH, Wahono SK, Maizirwan M, Nindita A, Purbajanti ED, Harsono SS, Malala AR, Nelwan LO and Sasmito A. 2017. Ballast weight review of capsule husk Jatropha curcas Linn. on acid fermentation first stage in two-phase anaerobic digestion. Proc. Pakistan Acad. Sci. B. Life and Environmental Sciences 54 (1): 47-57
Adiotomre KO. 2015. Production of bioethanol as an alternative source of fuel using Cassava and Yam Peels as raw materials. International Journal of Innovative Scientific \& Engineering Technologies Research, 3(2): 28-44.

Anindhita, Rahardjo I, Fitriana I, Dewi REP, Siregar E, Niode N, Yudiartono, Sugiyono A, La Ode, Wijaya WPT, Paminto AK, Gustriani N. 2018. Indonesia Energy Outlook 2018: Sustainable Energy for Land Transportation, 134 (4). BPPT, Jakarta, Indonesia.

Andres C, Adeoluwa O and Bhullar GS. 2016. Yam (Dioscorea spp.). In: Thomas B, Murry BG and Murphy DJ (Eds.) Encyclopedia of Applied Plant Sciences, Vol 3, Academic Press, Waltham, MA, USA pp. 435-441.

Azeteh IN, Hanna R, Sakwe PN, Njukeng AP and Kumar PL. 2019. Yam (Dioscorea spp.) production trends in Cameroon. Afr. J. Agric. Res. 14(26):1097-1110

Braide W, Oji IO, Adeleye SA and Korie MC. 2018. Comparative study of bioethanol production from agricultural wastes by Zymomonas mobilis and Saccharomyces cerevisiae. Int. J. Appl. Microbiol. Biotechnol. Res 6:50-60

Chen-Yeon Chu L, Biswarup Sen, Chyi-How Lay and Yi-Chun Lin. 2012. Direct fermentation of Sweet Potato to produce maximal hydrogen and ethanol. Appl. Energy, 100: 10-18.

Green RH and Maloney DW (Eds.). 2008. Perry's Chemical Engineers' Handbook, Eighth Edition, McGraw-Hill, USA

Hakim, M.L., Ongki W. dan Aulia A.A. 2017. Statistics of Agricultural Land 2012-2016. Center for Agricultura Data and Information System Secrtariat General - Ministry of Agriculture..

Kusmiyati. 2010. Comparasion of Iles-Iles and Cassava tubers as a Saccharomyces cerevisiae substrate fermentation for bioethanol production. Nusantara Bioscie. 2(1) : 7-13.

Mahasneh A M.,Sarah H and Sari A. M. 2015. Probiotic properties of Lactobacillus species isolated from local traditional fermented products. Jordan J. Biol. Sci. 8 (2) : 81 - 87

Novia N, Khairunnas and Purboyo GT. 2017. Effect of sodium hydroxide concentration during pretreatment and fermentation time on bioethanol levels from Pineapple leaves. Jurnal Teknik Kimia, 21(30):16-26

Obidiegwu JE and Akpabio EM. 2017. The geography of Yam cultivation in Southern Nigeria: Exploring its social meanings and cultural functions. J. Ethn. Foods, 4 (1): 28-35

Okongor, G., C. Njoku, P. Essoka and J. Efiong. 2021. Climate variability and Yam production: Nexus and projections. Sarhad $J$. Agric, 37(2): 406-418. 
Olayemia S, Ibikunleb A and Olayemic J. 2019. Production of ethanol from Cassava and Yam peels using acid hydrolysis. Am Sci Res J Eng Technol Sci. 52(1): 67-78

Praputri E and Sundari E. 2019. Production of bioethanol from Colocasia esculenta (L.) Schott (Talas Liar) by hydrolysis process. IOP Conf. Ser. Mater. Sci. Eng., 543(012056) :1-7

Purnomo A, Yulius AWY, Jindrayani NP, Adi TN, Wenny I, and Suryadi I. 2016. Subcritical water hydrolysis of Durian seeds waste for bioethanol production. Int J Ind Chem 7:29-37

Ramdath DD, Isaacs RLC, Teelucksingh S and Wolever TMS. 2004. Glycaemic index of selected staples commonly eaten in the Caribbean and the effects of boiling v. crushing. Br. J. Nutr., 91: 971-977

Ramesh, D, Manjunatha GR, Mishra P, Tailor, AK and. Dhekale BS. 2019. Design Experiments in the Basic of Statistics in Agricultural Sciences. Apple Academic Press Inc. Canada. pp 73-142.

Santos Michel Jr RJ, Canabarro NI, Alesio C, Maleski T, Laber T, Sfalcin P, Foletto EL, Mayer FD and Kuhn RC. 2016. Enzymatic saccharification and fermentation of rice processing residue for ethanol production at constant temperature. Biosyst. Eng., 142: $110-116$.

Selim KA, Dina EE, Saadia ME, and Mohamed IAH. 2018 Bioethanol a microbial biofuel metabolite. Fermentation 4 (16) : $1-27$.

Tampubolon BI and Fauzi A. 2016. Internalization of external costs and policy analysis for the development of geothermal energy as alternative energy. Jurnal Risalah Kebijakan Pertanian dan Lingkungan - Rumusan Kajian Strategis Bidang Pertanian dan Lingkungan, 2(2): 97-104.

Tanko M and Alidu A F. 2017. Profit efficiency of small scale yam production in Northern Ghana. Int J Dev Sustain , 5(1): 6982
Thatoi H, Krishna DP and Swain MR. 2016. Bioethanol production from tuber crops using fermentation technology: A review. Int. J. Sustain. Energy,35 (5): 443-468.

Ulyarti S and Lavlinesia DF. 2016. The study of physical properties of Dioscorea alata 's starch from Jambi Province. Int $J$ Adv Sci Eng Inf Technol., 6(4): 456-459.

UNESCO. 2020. Ecological Sciences for Sustainable Development. http://www.unesco.org/new/en/naturalsciences/environment/ecological-sciences/specificecosystems/drylands

Villadiego-del Villar AE, Sarmiento-Zea N, León-Pulido J and Rojas-Pérez LC. 2021. Bioethanol production from Yam (Dioscorea rotundata) using simultaneous saccharification and fermentation (SSF). TecnoL. 24(50) e1724:1-10

Winarti S and Saputro EA. 2013. Yam tuber flour prebiotic characteristic (Dioscorea spp.). Jurnal Teknik Kimia 8(1):17-21

Wuryantoro, Wardhani RM and Puspitawati IR. 2019. Yield test of 13 accession groups of Yam (Dioscorea alata L.) on three various agroecology. IOP Conf. Ser Earth Environ. Sci. 347 (012004): 1-6.

Wuryantoro, Praptiningsih GA and Wardhani RM. 2020. Study of planting models on growth and yield of "Uwi" (Dioscorea alata L.) Agri-Tek Journal Penelitian Ilmu-Ilmu Eksakta, 21(1):35-41.

Wuryantoro, Wardhani RM, Puspitawati IR, Adinurani PG and Yamin BM. 2021. Exploration and characterization of "Uwi" plant (Dioscorea sp.) in East Java uplands, Indonesia. E3S Web Conf. 226 (00049): $1-8$

Yasmin F, Radziah O. and Mohammad Nazmul HM. 2020. Yield and nutrient content of Sweet Potato in response of plant growthpromoting Rhizobacteria (PGPR) inoculation and $\mathrm{N}$ fertilization. Jordan J. Biol. Sci 13 (1) : 117-122. 